\title{
IAMJ
}

INTERNATIONAL

AYURVEDIC

MEDICAL JOURNAL

\section{HOLISTIC APPROACH IN MANAGEMENT OF AMAVATA W.S.R. TO CHAKRADATTA CHIKITSA SIDDHANTHA - A CASE STUDY}

\author{
$\underline{\text { Sayali Sampat Shinde }}^{1}$, Arun U. Bhatkar $^{2}, \underline{\text { Madhuri A. Pachghare }}^{3}$ \\ ${ }^{1}$ PG Scholar, Sanskrit Samhita and Siddhanta Department, Government Ayurved College, Nagpur, Maharashtra, \\ India \\ ${ }^{2}$ Head of Department and Associate Professor, Sanskrit Samhita and Siddhanta Department, Nagpur, \\ Maharashtra, India \\ ${ }^{3}$ Associate Professor, Sanskrit Samhita and Siddhanta Department, Nagpur, Maharashtra, India
}

Corresponding Author: saaushinde@gmail.com

https://doi.org/10.46607/iamj4909102021

(Published Online: October 2021)

Open Access

(C) International Ayurvedic Medical Journal, India 2021

Article Received: 15/09//2021 - Peer Reviewed: 05/10/2021 - Accepted for Publication: 06/10/2021

\section{Check for updates}

\section{ABSTRACT}

The impairment of Agni plays a very important role in Amavata. The name itself says there is the involvement of Ama and Vata. The Kha-vaigunya is observed mainly in Shleshmasthana (Asthisandhi) which results in Amavata. Use of Ayurvedic Diagnostics tools and then deciding Ayurvedic treatment helps to treat it in a natural way without any side effects and recurrence. Chikitsa Siddhanta as mentioned by Acharya Chakradatta for management of Amavata, consists of Langhana, Swedana, use of medicines having Tikta, Katu Rasa and Deepana property, Virechana, Snehapana and Basti. These modalities work mainly as Amapachana, Vatashamana, Strotoshodhana and Sthana Balya. Based on this Chikitsa Siddhanta, along with Langana, Swedana, Deepana, Pachana; Vaitaran Basti was administered in a case of Amavata which was successfully treated. Vaitaran Basti is also given by Chakradatta. Marked improvements were observed in signs, symptoms and RA factor after treatment. During the treatment, complications were not observed.

Keywords: Amavata, Ama, Chakradatta, Vaitaran basti, RA factor. 


\section{INTRODUCTION}

The Anshaansha Samprapti (Fractional Path) of Amavata disease involves Vyana Vayu, Pachak Pitta, Kledaka and Shleshmak Kapha. The main dushya involved is Rasa Dhatu and Strotas is Rasavaha Srotas. The foremost important factor is Jatharagni Mandhya. In Amavata type of srotas dusti is Sanga and Khavaigunya is Sandhi. The aggravated Vata carries Ama which is produced because of agnimandya and deposits it in Sleshmasthanas (Sites of kapha like joints etc.). The clinical features of Amavata produced are Angamarda (body ache), Aruchi (loss of appetite), Alasya (weakness), Sandhiruk (joint pain), Sandhishotha (joint swelling) and Sandhisthabdata (joint stiffness) [1]. The detailed description of Amavata an ayurvedic perspective was firstly described by Madhavakara (700 A.D.) in Madhava Nidana whereas the treatment of Amavata was first explained by Acharya Cakradatta. Being a disease of Madhyama Rogamarga it is said to be Krichrasadhya or Yapya. Amavata affects the daily routine of patients which hampers his/her working ability. Due to the physical impairment, it indirectly affects the mental state also. Due to these reasons, it is one of the burning problems.

The Rheumatoid arthritis disease closely resembles Amavata. So, the prevalence of RA is taken into consideration which is approximately $0.8 \%$ of the population ${ }^{[2]}$; Also, to investigate the improvement of this case study reports of RA factor before and after treatment is taken into consideration along with signs and symptoms. Almost $80 \%$ of all patients develop the disease between the ages of 35 and 50. ${ }^{[2]}$

The focus of Ayurveda is to break the path of disease by focusing on the causative factor. Here, the main causative factor is Agni-Mandhya which produces Ama and Paratantra dosha prakopa. Acharya Chakradatta described the Chikitsa Siddhant for Amavata which includes Langhana, Swedana and use of drugs having Tikta, Katu Rasa with Deepana property, Virechana, Snehapana and Basti ${ }^{[3]}$. Among these Vaitaran Basti is also a specific modality for Amavata which is explained under Niruha Adhikara by Acharya Chakraddtta. Vaitaran Basti is said to work on Shool, Aanaha and Amavata. ${ }^{[4]}$ Here a case of Amavata was treated by using Siddhanta of Chakradatta and Vaitaran basti.

\section{CASE REPORT}

A 49-year male patient working as an employee in High Court visited OPD (CR No.6360) of Panchakarma, Government Ayurveda Hospital and College, Nagpur, Maharashtra, having complaints of Shool, Sthamba and Shotha in Sandhi pradeshas since 4 yrs, and Agni-mandhya and Jwara for 7 days and Sandhi-graha in the morning is more for 1 month. The patient had episodes of Jwara twice a week for 3 months. The patient was alright before 4 years. Gradually Patient faced problems in daily routine like walking, sitting etc. Later, Jwara along with shool and shotha started in both Janu Sandhi (knee joints). Thereafter he developed Shoola in the remaining Sandhis. There was significant Sparshaasahatwa (Tenderness). Before every episode of Jwara patients complains of loss of appetite and morning stiffness. For that, he took allopathic treatment but did not get satisfactory results and for further management, he came to GAHC, Nagpur.

\section{PAST MEDICAL HISTORY}

There was no history of Diabetes, Hypertension or any other major illness in the past.

The patient was under allopathy treatment and was taking Steroids for the past 3 years.

Accident 24 yrs ago.

\section{FAMILY HISTORY}

Matruja Vrutta - Ovarian Cancer.

Pitruja Vrutta - Rheumatoid Arthritis.

Swakul Vrutta - Brother - Rheumatoid Arthritis.

\section{EXAMINATION}

Nadi (Pulse) - Manda gati; Kapha-Vataj; 68/min.

Mala Pravrutti - Once daily, Sama, 'Krute api akruta saudnyata'.

Mutra Pravrutti-7-8/day

Jivha - Saam.

Swasana - 18/min

Blood pressure $-100 / 70 \mathrm{mmHg}$ 


\section{LOCAL EXAMINATION}

Shotha presents on both Manibandha (wrist joints) and Janu (knee joints) Sandhis.

Sthamba along with Shotha and Shoola in both Aunsa sandhis (shoulder joints).

Slight Shoola and Shotha in Parva Sandhis and Both Gulpha Sandhis (Ankle joints).

Shoola in Manya Sandhi (Cervical Joint)

Sparsha-Ushna.

Range of movement - Restricted and painful movement of joints.

\section{EXAMINATION OF SROTAS}

- Vikruta Srotas - Annavaha Srotas, Rasavaha Srotas, Mansavaha Srotas, Medovaha Srotas, Majjavaha Srotas and Purishavaha Srotas.

- Vikruti Swarupa - Sanga and Vimargagamana.

DUSHTA DOSHA, DUSHYA AND MALA NIRDESHA:

- DOSHA - Vyana vayu, Pachak Pitta, Kledak kapha and Sleshaka kapha.
- DUSHYA - Mansa, Meda and Asthi.

- MALA - Purisha.

\section{DIFFERENTIAL DIAGNOSIS}

Amavata, Sandhivata, Vatarakta.

[Sanchari Vedana, Samata, Involvement of Bruhat sandhi and Agni-Mandya. Increase in intensity of pain in cloudy weather. Increase in pain on the application of oil.]

INVESTIGATIONS DONE

CBC, KFT, LFT, RA Factor.

\section{DIAGNOSIS}

Amavata as per Hetus (causative factor) and Lakshanas (symptoms) described in the classics of Ayurveda.

\section{TREATMENT PLAN}

The treatment was planned in Two Phases.

First Phase:

Langhana: For 7 Days.

Table 1

\begin{tabular}{|l|l|}
\hline FIRST MEAL & SECOND MEAL \\
\hline 2 Chapatis and Curry & Sali Lahya (popped rice)
\end{tabular}

*Warm water for drinking. If a patient experienced hunger after the first meal, he was advised to take only Sali Lahya (popped rice).

1) Abhyantar Chikitsa (Internal medication) along with Bahya Chikitsa (External medication):

Table 2: Abhyantar Chikitsa (Internal medication) Advised after 3 days of Langhana.

\begin{tabular}{|r|l|l|l|l|l|}
\hline Sr.No. & Medicine & Dose & Anupana & Kala & Duration \\
\hline 1. & Tribhuvanakirti rasa & $125 \mathrm{mg}$ twice & Koshna jala & Apana & 7 days \\
\hline 2. & Sihanad Guggulu & $500 \mathrm{mg}$ twice & Koshna jala & Apana & 7 days \\
\hline 3. & Gandharva Hastakadi Kashaya & $15 \mathrm{ml} \mathrm{twice}$ & $\begin{array}{l}\text { Equal quantity } \\
\text { of Koshna jala }\end{array}$ & After meal & 7 days \\
\hline
\end{tabular}

Table 3: Bahya (External Treatment): Advised after 3 days of Langhana.

\begin{tabular}{|l|l|l|}
\hline Local Procedures & Medications & Duration \\
\hline Snehana & Mahavishgarbha Tail & 30 Days \\
\hline Swedana & Valuka Pottali & 30 Days \\
\hline
\end{tabular}

Second Phase: After proper langhana and deepana next phase was advised. Episodes of jwara were not observed for more than 10 days. So, Basti was planned. 
Table 4: Basti Charting:

\begin{tabular}{|l|l|l|l|}
\hline DATE & BASTI & QUANTITY & DHARAN KALA \\
\hline $1 / 2 / 2019$ & Anuvasan basti & $60 \mathrm{ml}$ & 6 hours \\
\hline $2 / 2 / 2019$ & Vaitaran basti & $350 \mathrm{ml}$ & 5 minutes \\
\hline $3 / 2 / 2019$ & Anuvasan basti & $60 \mathrm{ml}$ & 3 hours \\
\hline $4 / 2 / 2019$ & Vaitaran basti & $350 \mathrm{ml}$ & 10 minutes \\
\hline $5 / 2 / 2019$ & Vaitaran basti & $350 \mathrm{ml}$ & 25 minutes \\
\hline $6 / 2 / 2019$ & Vaitaran basti & $350 \mathrm{ml}$ & 30 minutes \\
\hline $7 / 2 / 2019$ & Vaitaran basti & $350 \mathrm{ml}$ & 25 minutes \\
\hline $8 / 2 / 2019$ & Vaitaran basti & $350 \mathrm{ml}$ & 5 minutes \\
\hline $9 / 2 / 2019$ & Anuvasan basti & $60 \mathrm{ml}$ & 5 hours \\
\hline $10 / 2 / 2019$ & Anuvasan basti & $60 \mathrm{ml}$ & 9 hours \\
\hline $11 / 2 / 2019$ & Vaitaran basti & $350 \mathrm{ml}$ & 5 minutes \\
\hline $12 / 2 / 2019$ & Vaitaran basti & $350 \mathrm{ml}$ & 5 minutes \\
\hline $13 / 2 / 2019$ & Vaitaran basti & $350 \mathrm{ml}$ & 5 minutes \\
\hline $14 / 2 / 2019$ & Anuvasan basti & $60 \mathrm{ml}$ & 5 hours \\
\hline
\end{tabular}

Vaitaran Basti contents: Pakva Amlika 40 gms, Jaggery 20 gms, Saindhava 10 gms, Sahachara taila
$80 \mathrm{ml}$, Gomutra $180 \mathrm{ml}$. (quantity of one basti).

* Anuvasana - Sahachara Taila.

Table 5: Pathya-apathya (dos and don'ts) - Advised to the patient as follow:

\begin{tabular}{|l|l|}
\hline Pathya & $\begin{array}{l}\text { AHARAJA: Sali Lahya (popped rice), Bajri (Millet), Yava (barley), kulattha (horse gram), raktashali (rice), } \\
\text { shigru (drumsticks), punarnava, karvellak (bitter gourd), parawar, ardrak (ginger). rasona or ginger shodhit } \\
\text { with takra. Jangal mansa (meat). Hot water. } \\
\text { VIHARAJA: Sunlight exposure for at least } 15 \text { minutes a day. } \\
\text { Pranayam, yoga, meditation. Hot water bath. Walking in between breaks. 8hrs sleep at night. }\end{array}$ \\
\hline $\begin{array}{l}\text { Ap- } \\
\text { athya }\end{array}$ & $\begin{array}{l}\text { AHARAJA: Flour of mash (black gram), Rajmah (kidney beans), sweets, Milk products, Fast food, uncooked } \\
\text { food, salty, spicy, oily food, Fish, Coldwater, Curd, jaggery, milk, cold beverages, ice creams. } \\
\text { VIHARAJA: Daytime sleeping, vegavadharan (suppression of natural urges); exposure to cold, wind, A.C., } \\
\text { excess of stress, Sitting in one place for a long period of time. }\end{array}$ \\
\hline
\end{tabular}

Follow up - After 60 days

ASSESSMENT CRITERIA: The assessment was done on the day prior to initiation of treatment and on the day of completion of treatment (Day 26). Grading of subjective criteria is shown in tables $6,7,8$ and 9 and Objective criteria are shown in table no. 9

Table 6: Grading of Sandhishoola (pain)

\begin{tabular}{|l|l|l|}
\hline Sr.no & Severity of Pain & Grade \\
\hline $\mathbf{1}$ & No pain & 0 \\
\hline $\mathbf{2}$ & Mild pain & 1 \\
\hline $\mathbf{3}$ & Moderate, but no difficulty in moving & 2 \\
\hline $\mathbf{4}$ & Much difficulty in moving the body parts & 3 \\
\hline
\end{tabular}


Table 7: Gradng of Sandhishotha (swelling)

\begin{tabular}{|l|l|l|}
\hline Sr.no & Severity of swelling & Grade \\
\hline $\mathbf{1}$ & No swelling & 0 \\
\hline $\mathbf{2}$ & Slight swelling & 1 \\
\hline $\mathbf{3}$ & Moderate swelling & 2 \\
\hline $\mathbf{4}$ & Severe swelling & 3 \\
\hline
\end{tabular}

Table 8: Grading of Sparshasahatwa (tenderness)

\begin{tabular}{|l|l|l|}
\hline Sr.no & Severity of tenderness & Grade \\
\hline $\mathbf{1}$ & No tenderness & 0 \\
\hline $\mathbf{2}$ & The subjective experience of tenderness & 1 \\
\hline $\mathbf{3}$ & Wincing of the face on pressure & 2 \\
\hline $\mathbf{4}$ & Wincing of face and withdrawal of the affected part on the pressure & 3 \\
\hline
\end{tabular}

\section{OBJECTIVE CRITERIA:}

Table 9: Gradation of Walking time

\begin{tabular}{|l|l|l|}
\hline Sr.no & Walking time (for 25 feet in several seconds) & Grade \\
\hline $\mathbf{1}$ & $15-20 \mathrm{sec}$ & $\mathbf{0}$ \\
\hline $\mathbf{2}$ & $21-30 \mathrm{sec}$ & $\mathbf{1}$ \\
\hline $\mathbf{3}$ & $31-40 \mathrm{sec}$ & $\mathbf{2}$ \\
\hline $\mathbf{4}$ & $>40 \mathrm{sec}$ & $\mathbf{3}$ \\
\hline
\end{tabular}

\section{OBSERVATIONS AND RESULTS}

The observation and results are displayed in Tables 10 , 11, 12, 13 and 15. Figures 1 and 2 represent the improvement in objective criteria assessment of the patient

Table 10: Assessment of Sandhishoola

\begin{tabular}{|c|c|c|c|c|}
\hline Left & & of joint & ght & \\
\hline BT & AT & & BT & AT \\
\hline 3 & 1 & Cervical joint & 3 & 1 \\
\hline 3 & 1 & Shoulder joint & 3 & 1 \\
\hline 2 & 0 & Wrist joint & 2 & 0 \\
\hline 2 & 0 & Metacarpophalangeal j. & 3 & 0 \\
\hline 3 & 1 & Knee joint & 3 & 1 \\
\hline 2 & 0 & Ankle joint & 2 & 0 \\
\hline
\end{tabular}

Table 11: Assessment of Sandhishotha

\begin{tabular}{|l|l|l|l|l|}
\hline Left & Name of joint Right & \multicolumn{1}{l|}{} \\
\hline BT & AT & BT & AT \\
\hline 2 & 0 & Cervical joint & 2 & 0 \\
\hline 3 & 1 & Shoulder joint & 3 & 1 \\
\hline 2 & 0 & Wrist joint & 1 & 0 \\
\hline 2 & 0 & & 2 & 0 \\
\hline
\end{tabular}




\begin{tabular}{|l|l|l|l|l|}
\hline 3 & 1 & $\begin{array}{l}\text { Metacarpophalangeal j. } \\
\text { Knee joint } \\
\text { Ankle joint }\end{array}$ & 2 & 1 \\
\hline
\end{tabular}

Table 12: Assessment of Sparshasahatwa

\begin{tabular}{|l|l|l|l|l|}
\hline Left & \multicolumn{5}{|c|}{ Right } \\
\hline BT & AT & & BT & AT \\
\hline 3 & 1 & Shoulder joint & 3 & 1 \\
\hline 2 & 0 & Wrist joint & 1 & 0 \\
\hline 3 & 1 & Knee joint & 3 & 1 \\
\hline
\end{tabular}

Table 13: Assessment of Objective Criteria

Criteria

Walking time (for 25 feet in several seconds)

\begin{tabular}{|l|l|}
\hline BT & AT \\
\hline 2 & 1 \\
\hline
\end{tabular}

\section{INVESTIGATIONS}

Table 14: Showing Laboratory values on admission

\begin{tabular}{|l|l|}
\hline Investigations & \multicolumn{1}{|c|}{ On admission } \\
\hline $\mathrm{Hb} \%$ & $13.7 \mathrm{gm} \%$ \\
\hline TLC & $8,200 / \mathrm{cumm}$ \\
\hline Neutrophils & $90 \%$ \\
\hline Lymphocytes & $34 \%$ \\
\hline Monocytes & $2 \%$ \\
\hline Eosinophils & $1 \%$ \\
\hline Total Platelet Count & $2.52 \mathrm{Lacs} / \mathrm{cu} . \mathrm{mm}$ \\
\hline ESR & $48 \mathrm{~mm} / \mathrm{hr}$ \\
\hline Blood urea & $16.2 \mathrm{mg} / \mathrm{dl}$ \\
\hline Serum creatinine & $1.26 \mathrm{mg} / \mathrm{dl}$ \\
\hline Uric acid & $8.0 \mathrm{mg} / \mathrm{dl}$ \\
\hline SGOT & $22.5 \mathrm{U} / \mathrm{L}$ \\
\hline SGPT & $14.0 \mathrm{U} / \mathrm{L}$ \\
\hline Bilirubin (total) & $0.38 \mathrm{mg} / \mathrm{dl}$ \\
\hline Billirubin (direct) & $0.26 \mathrm{mg} / \mathrm{dl}$ \\
\hline RA Factor & $1260 \mathrm{IU} / \mathrm{ml}$ \\
\hline
\end{tabular}

Among the above values, RA factor and ESR showed significant change after treatment which is as follow: 
RA Factor Values Before Treatment and After Treatment:

\begin{tabular}{|l|l|l|}
\hline RA Factor & BT (24/01/2019) & AT (14/02/2019) \\
\hline ESR & $1260 \mathrm{IU} / \mathrm{ml}$ & $122 \mathrm{IU} / \mathrm{ml}$ \\
\hline
\end{tabular}

\section{Figure 1}

Graph showing the change in RA factor Values

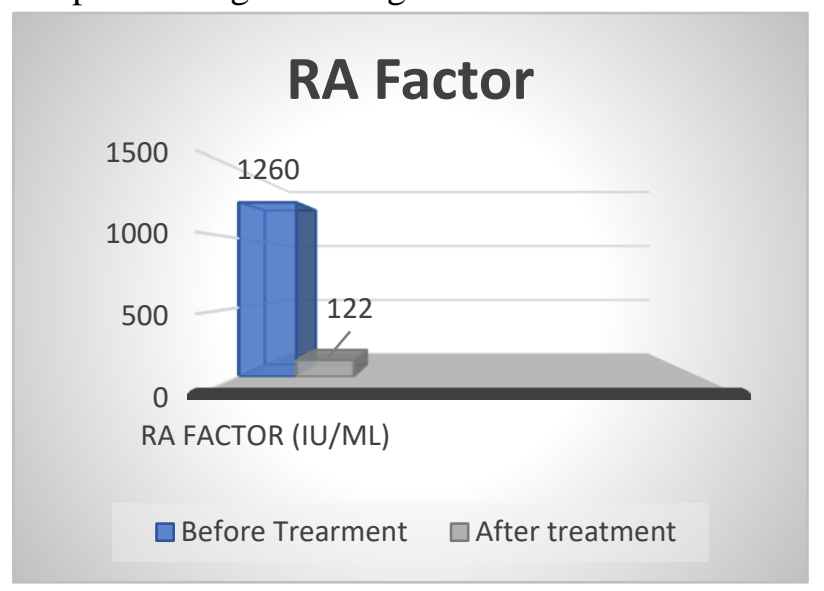

\section{DISCUSSION}

The Chikitsa Siddhant for Amavata was firstly described by Chakradatta. It includes Langhana, Swedana, drugs having Tikta, Katu Rasa and Deepana action, Virechana, Snehapana and Basti. ${ }^{[3]}$ Amavata is mainly caused due to impairment of Agni leading to the formation of $A m a^{[5]}$ also there is vitiation of Vata dosha. Langhana was advised to the patient. Only two meals were advised as per hunger among which dinner consist of Sali Lahya. Proper and strict langhana was the main key to treatment. The first line of treatment in Amavata is Langhana as it is Amasayotha vyadhi and Rasaja Vikara. Tribhuvankirti Rasa $125 \mathrm{mg}$ twice a day, Sinhanad Guggulu $500 \mathrm{mg}$ twice a day and Gandharwahastyadi Kashaya $10 \mathrm{ml}$ twice a day with lukewarm water were given to the patient. Tribhuvankirti Ras is Jwaraghna (antipyretic), Swedajanana (induce sweating), Vedanahara (relieves pain), Shothaghna (reduces swelling) and Enhances AgniBala (digestive and metabolic capacity). ${ }^{[6]}$ It was administered for about 7 days to break the samprapti of Jwara. Sinhanada Guggul has Laghu, Ruksha, Ushna, Tikshna properties. Sinhanada Guggul has Deepana (enzyme activating), Ama-Pachan (biotoxin

\section{Figure 2}

Graph showing the change in ESR values

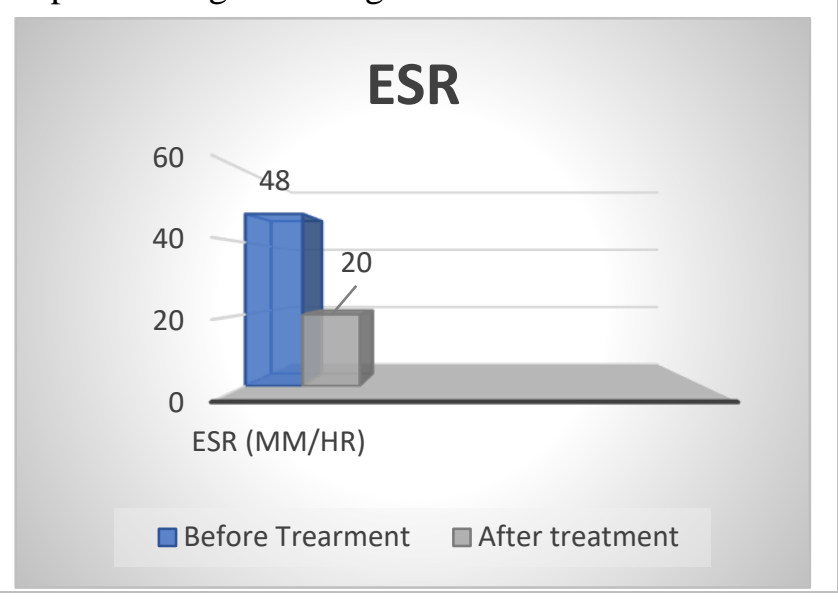

neutralizing), Shothaghna (oedema reducing), Shoolghna (analgesic), Jwaraghna (antipyretic), Balya (energy-enhancing) and Amavatahara (anti-rheumatic) properties. It enhances the Agni- Bala (digestive and metabolic capacity), alleviates the Ama (biotoxins) and prevents further Ama (biotoxins) formation into the body. ${ }^{[7]}$ The main purpose of Sinhanad guggulu is to administer deepana and Ama pachana. Gandharwa Hastyadi Kshaya is Vataghna (vata disorders), Agni deepan (Enhances digestion capacity), Works on Anorexia and is a Mala Shodhaka (Enables evacuation of the bowel) i.e., acts as a Mrudu Virechaka. It was mainly administered to work on Annavaha Srotas, Rasavaha Srotas and Purishavaha Srotas. Mahavishgarbh Tail contains vatahar drugs like Dhatura (Datura mete linn), Vatsanabha (Aconitum Ferox), Eranda (Ricinus communis), etc. These drugs have vedanasthapana, shothahar, swedajanana, dipana and pachana properties which help to relieve the pain by vatashaman and causes amapachana on local application ${ }^{[8]}$ Due to the presence of Ama, Ruksha Swedana has been specially indicated in the presence of Stambha, Gaurava and Shoola. ${ }^{[9]}$ Rukshasweda has been advocated in the form of Valukapottali. It helps 
in pacifying Samata thus leading to relieving pain and stiffness. After around 10 days of Langhana, Deepana and Pachana, Basti was administered. Basti to be given was decided based on Lakshanas. Vaitaran Basti is said to have a very potent cleansing action. ${ }^{[10]}$ It is mentioned by Chakradatta in Niruhaadhikara chapter verse 73/32. Vaitaran Basti causes the liquefication in doshas and digestion of Ama which leads to Srotas Shuddhi thereby controlling the Vata Dosha. The vitiated doshas are then expelled out from the anal root by Basti. To avoid Vata prakopa due to Niruha basti (Vaitaran), Anuvasana Basti is administered as per need. Vaitarana basti is considered as Laghu, Ruksha, Ushna and Tikshna Guna. All these properties are opposite to that of Ama. Hence, it provides significant improvement in the Signs and symptoms of Amavata. The assessment of the patient before and after treatment was taken which showed improvements within the subjective and objective criteria. Also, significant changes in RA factor values.

\section{CONCLUSION}

From this case study, it can be concluded that Amavata can be effectively and safely treated by using Chikitsa Siddhant and Vaitaran Basti described by Acharya Chakradatta. There is a need to conduct a study on many patients.

\section{REFERENCES}

1. Madhavakara, Madhavanidana, Vimala Madhudhara Teeka by Tripathi Brahmanand, Varanasi. Chaukhambha Surabharati Prakashana, ed. 2010, Poorvardha, Chapter-25, p. 571-577.

2. Churchill L., Davidson's Principle and Practice of Medicine. 19th ed.: Elsevier Publication; 2002. p. 1002-7.

3. Bajpeyee J., Chakrapani Datta. Amavatarogadhikara 25/31-36. Kalyan-Bombay. The Proprietor, Shri Laxmi Venkateshwar Steam Press; 1998. p.167-168.

4. Bajpeyee J., Chakrapani Datta. Niruha-adhikara 73/3234. Kalyan-Bombay. The Proprietor, Shri Laxmi Venkateshwar Steam Press; 1998. p.332.

5. Tripathi R., Charaka samhita with Vidyamanorama Hindi commentary, Nidanasthna 8/31, Delhi, Chaukhamba Sanskrit Pratishthan, 2009. p. 542.
6. Gune G. Ayurvediya Aushadhigunadharmashastra. Part -3. Tribhuvankirti Ras. Delhi. Chaukhamba Sanskrit Pratisthana. Ed.2021. p.52.

7. Das G., Bhaishajya Ratnavali, Hindi commentary by Ambikadatta Shastri, Varanasi, Chaukhambha Prakashana, Edition2014, Amavata chikitsa, 29/181-189. p.628

8. Das G., Bhaishajya Ratnavali Volume -II, English commentary by Kaajiv alaochan, Varanasi, Choukhambha Sanskrit Bhavan, chapter 26, Verse593-606; 2005. p.233.

9. Tripathi R., Charaka samhita with Vidyamanorama Hindi commentary, Delhi, Chaukhamba Sanskrit Pratishthan, 2009. Sutrasthan 22/11. p.309

10. Wetal V.R., Huperikar R. Study of the effect of Vaitarana Basti in Amavata: A clinical trial. Int. J. Ayu. Pharm chem. 2016;4(2): p.38-45.

\section{Source of Support: Nil Conflict of Interest: None Declared}

How to cite this URL: Sayali Sampat Shinde et al: Holistic Approach In Management Of Amavata W.S.R. To Chakradatta Chikitsa Siddhantha - A Case Study. International Ayurvedic Medical Journal \{online\} 2021 \{cited October 2021\} Available from: http://www.iamj.in/posts/images/upload/2590_2597.pdf 